\title{
Quotation as a Poetic Device in a Romanian Postmodern Corpus. A Pragmasemantic Approach
}

\section{CARMEN POPESCU}

\begin{abstract}
The paper highlights the complex functioning of quotation in the context of Romanian postmodern poetry, focusing on a pragmasemantic approach, where the communicational dimension of the poetic process is underscored. A special place is granted to the theory of quotation, by reviewing various models, which range from the intertextual and dialogicpolyphonic account to the one grounded in the linguistics of enunciation as well as in language philosophy. The illustrations are taken from a corpus of contemporary poetry, starting with Cristian Popescu's "All This Had to Bear a Name", where the quotational paratext (the title) establishes a parodic relationship with a previous poem by Marin Sorescu. This "second-order" text does not refute the strict meaning of the original (in fact, it does not mention its theme, the Romantic poet Eminescu) but it directs its deconstructionist drive towards another cultural fetish, the ballad The Little Ewe, equally a part of the official vulgate, a cultural "monument". Examples borrowed from Radu Andriescu or Letitia Ilea reveal the self-reflective use of language and also the close relationship that citation entertains with reported speech, represented discourse and the very complex phenomenon of polyphony as described by Bakhtin. Inside the texture of the postmodern poem, the grafting of alien discourses rarely reifies textual otherness and more often than not handles the quotation as manifestation of a particular voice, with which the poetic subject engages dialogically. Even so, the deconstruction of clichés and doxa or common opinion is crucial in this poetics. Along with the pervasive palimpsest, quotation in a poetic context also has important metalinguistic and metaliterary effects, by enhancing the literariness of literature.
\end{abstract}

Keywords: quotation, intertext, parody, pragma-semantic approach, postmodernism

\section{Introduction}

Romanian postmodernism is neither the product of "late capitalism" (Jameson 1991), nor of post-industrial or consumer society, but a cultural import, and a cultural palimpsest in itself. While "the ironic dialogue with the past" and 
the propensity for "critical reworking" (Hutcheon 1988: 4) of traditional forms are features easily identifiable in the Romanian version of postmodernism as well, the cultural and political content of that past is not exactly the same as in Western postmodernism. Apart from "naturalizing" the postmodern paradigm, the Romanian promotion of the eighties has absorbed the basic tenets of semiotics. Intertextuality is a major component of the model. With poets of the eighties, quotation is turned into a poetic device per se:

For each particular text the reader has to determine if the quotation is autonomous with respect to the deep structure, in this case its function being that of a figure of speech, or if it is inserted in the deep structure, thus becoming a meaning-generating metaphor. (Parpală-Afana 1994: 72)

Inside the poetic discourse, quoted elements will generate semantic and pragmatic complexity: "Thus, as a general rule, a quotation does not only include a single (isotopic) but two or more (poly-isotopic) levels of meaning that need to be interrelated by the recipient" (Plett 1991:10).

Recycling of previous discourse has remained a hallmark of even more recent poetry, although it tends to be less bookish and elitist and more open to the new media. In Romanian poetic postmodernism, quotation may have the function of various rhetoric strategies: metaphor, metonymy, syllepsis (for the last trope, see Riffaterre 1979a). Most of the times, either the signifier or the signified of the quoted excerpt are affected by the poetic treatment, or both at the same time, thus engendering a significant shift in the poetic meaning.

The goals of the pragmasemantic approach are:

1) to assess the communicative functions of quotations in a poetic context;

2) to determine the consequences of the textual graft with respect to the structure and significance of embedding poems;

3) to contrast the standard (scientific) use of quotation to the literary use.

\section{Theoretical framework}

My approach is twofold: 1) intertextual-polyphonic (Barthes 1977, Kristeva 1980, Compagnon 1979, Riffaterre 1979a, 1979b, 1990, Genette 1998) and 2) linguistic-philosophical (Davidson 1984, Recanati 2001, Saka 2005, Cappelen \& Lepore 2007), but with a semiotic (and particularly pragmatic) focus in each of the two fields. As the most obvious presence of the other's discourse inside one's own, quotation epitomizes, in a way, the entire practice of intertextuality. Inside the first line of analysis, Kristeva and Barthes illust- 
POPESCU

rate the poststructuralist framework, where the concept of intertextuality was coined. Here quotation and intertext had been used rather loosely: "any text is constructed as a mosaic of quotations" (Kristeva 1980: 66), any text is "a tissue of quotations" (Barthes 1977: 142). According to Barthes, the "quotations" of which the text is made are "anonymous, irrecoverable and yet already read: they are quotations without quotation marks" (ib.). Antoine Compagnon has dedicated an entire volume to quotation (1979), where he outlines a "phenomenology", a "semiotics", a "genealogy" and a "teratology" of quotation, whereas Genette, the author of Palimpsests (1982), defines quotation as "the actual presence of a text within another" (1997: 1-2). In Riffaterre's semiotic model, quotation is an "intertextual interpretant" (1979b). On the second approach, quotation is described as a form of reported speech or represented discourse. All these authors agree that quotation is a topic relevant for the semantics / pragmatics interface. This type of analysis is also the basis for contrasting poetic quotation with the normal or standard use (and status) of the device.

On the background of this theoretical account, the demonstrative theory (Davidson 1984) seems to be the most appropriate for literary analysis. Demonstrations belong to "a family of nonserious actions that includes practicing, playing, acting and pretending” (Clark \& Gerrig 1990: 766). Indeed, in the corpus under scrutiny, many playful effects are attained by simulating misquoting (the erroneous or dishonest version of scientific citation). According to a more recent version of the demonstrative theory, quotations are seen as pictures, whereby "the quoted material is displayed or presented" (Recanati 2001: 639). Although not all quotations are mimetic, "all quotations are iconic" (ib. 645).

\section{Quotation in poetry}

Quotational practices are signifying practices and, in the broadest sense, communicative strategies. Postmodern culture is sometimes perceived as "a palimpsest of citations and quotations that are half-recognized" (Garber 2003: 6). Nevertheless, a universal grammar of quotational strategies is apparently not within our reach, despite undeniable invariants which have been emphasized by logical description and formalization. M. Bakhtin claimed that quotational styles are historically and culturally differentiated. In the Hellenistic period (in many respects a cultural age as heteroclite and diversified as the postmodern age) he identified a stylistic feature which he termed "the problem of quotation": 
Quotation as a Poetic Device in a Romanian Postmodern Corpus

The forms of direct, half-hidden and completely hidden quoting were endlessly varied, as were the forms of framing quotations by a context, forms of intonational quotation marks, varying degrees of alienation or assimilation of another's quoted word. And here the problem frequently arises: is the author quoting with reverence, or on the contrary, with irony, with a smirk? Double entendre as regards the other's word was often deliberate. (Bakhtin 1981: 6869)

Since the modernist movement, quotation has been more and more present in poetry. Two studies (Diepeveen, 1993, Gregory, 1996) have focused on this issue, with application to modern American poetry. Before the early part of the twentieth century, when American poets like Pound, Zukofsky, Williams, Moore, Brown and Crane started to "employ borrowed words meant to be recognized as such", allusion was "the preferred and time-honored mode of intertextual reference in poetry", while quotation appeared rather rarely (Gregory 1996: 2). While Gregory addresses issues of cultural authority emerging in the quoting process, as well as American "secondariness", Leonard Diepeveen had previously argued for the structural effects that the exact duplication of a different texture has on the "modern quoting poem" (1993). Alien discourses leave a mark, and quotations are chosen due to their "idiosyncratic texture" and "unparaphrasable content" (Diepeveen 1993: 2-3). Together with the alternating voices it engenders, this technical change also affects the reading process. In other words, it has important pragmasemantic implications.

Modernist innovations have been prolonged, refined and radicalized by postmodernism. Quotation as a postmodern dominant should be somehow correlated with postmodernism's most important features. Among these, I would highlight Jameson's judgement about "the emergence of a new kind of flatness or depthlessness, a new kind of superficiality in the most literal sense" (1991: 68). Choosing quotation over allusion might entail bringing to the surface the processes that were supposed to take place in the intricacies of the poetic realm and in the intimacy of the poet's relation with tradition's otherness. Another postmodern characteristic that might be relevant for a renewed interest in quotation is Ihab Hassan's observation about a paratactic postmodernism as opposed to the hypotactic modernism (1987: 90-91). To sum up the two arguments: depth and hierarchy, already questioned by modernists, are utterly undermined by postmodern artists. 
POPESCU

The pragmatics of quotation in the paratexts. "All This Had to Bear a Name" or the palimpsestic logic of cultural signs

Any text's paratextual apparatus is rich in pragmatic signals. In fact, we could assert that the paratext's ontology is pragmatic by excellence. Paratextuality is the (communicative) space of liminality, a threshold, and one of its major coordinates is its illocutionary force: "This fringe, in effect, [...] constitutes, between the text and what lies outside it, a zone not just of transition, but of transaction; the privileged site of a pragmatics and of a strategy, of an action on the public [...]" (Genette 1997: 3). According to Genette, the paratext divides into peritext, i.e., paratext placed inside the book, from prefaces to blurbs, and epitext, a series of additional materials which help explain the text but are physically located outside it (interviews, advertisements, etc). In Romanian postmodern poetry, quotation may appear in titles, subtitles, epigraphs, footnotes, which are all instances of the peritext, with a clear pragmatic bearing on the poetic meaning (cf. Popescu 2010).

"All This Had to Bear a Name", a poem by Cristian Popescu ("Trebuiau să poarte un nume", in the volume Arta Popescu, 1994), is a parodic palimpsest to a famous poem by the same title written by Marin Sorescu (Poeme 1976). The paratext is consequently an explicit quotation, working as a signal of intertextual reference, and also of metatextual, self-referential commentary. Due to the fact that the source is not given - as, for instance, in an infra-title note like "After Marin Sorescu", the quotation can also be considered a limit-case of an allusion. There is a strong pragmatic dimension of the paratext reflected in its function of suggesting a line of interpretation. It is the quotation in the title (complete with quotation marks) that turns the poem into a palimpsest, that is, a hypertext which requires reading through constant paralleling with the suggested hypotext. An important task is ascribed in the text to the quotation marks in the title: these graphic signs are meant to make the difference between reverent and irreverent quotation, between pastiche and parody.

The use of quotation marks appears to be somehow excessive, considering the target's notoriety, for Romanian readers. If quotation marks "are used to signal mentioning and thus serve to disambiguate" (Saka 2005: 187), this careful acknowledgement of the borrowing might indicate the inclination towards transitivity and the half-serious preoccupation of "educating" the readership that is characteristic to at least a part of the postmodern production. But this very ostentatious manner of revealing the derivative nature of the text is also a marker of irony. Inverted commas are here used for citational mentioning and at the same time for ironic distancing, as in the case of "scare 
quotes". Marjorie Garber points out: "one of these curious properties of these typographical signifiers; for in their present condition of use, they may indicate either authenticity or doubt" (2003: 8). A typical postmodern ambivalence can therefore be read in this double function of inverted commas. As the same author argues with respect to ironic quotes:

Some users call these protestation marks, indicating that they are the performed equivalent of what Jacques Derrida, following Martin Heidegger, has termed being "under erasure" - a word with a horizontal line drawn through it to indicate that it demarcates a nodal idea - for which the present word is inappropriate or insufficient: man, freedom, justice. (Garber 2003: 8)

The hypotext of the palimpsest I am referring to is a poem about Mihai Eminescu's mythical stature. Marin Sorescu (1936-1996) is the most translated Romanian poet and playwright; he has received many international awards and was even a candidate for the Nobel Prize for literature. A great ironist himself, he made his literary debut with a volume of parodies and pastiches, Alone among Poets, 1964; in the numerous volumes that followed, he has developed a successful formula: he managed to convey metaphysical parables in a playful, derisive but still elegant manner. In the Introduction to Sorescu's volume of translated poems Hands behind My Back, Seamus Heaney has pointed out that behind the author's "throwaway charm and poker-faced subversiveness; [...] there is a persistent solidarity with the unregarded life of the ordinary citizen, a willingness to remain at eye-level and on a speaking terms with common experience" (Sorescu 1991: 14).

The Romantic poet Mihai Eminescu (1850-1889) enjoyed a special cult during the communist period, when the nationalistic tendencies of the public discourse became rampant. Eminescu was called the "national poet" and every evocation and homage of this iconic figure was expected to be solemn, encomiastic and "poetic" (that is, highly metaphorical). Sorescu's poem brought about a major shift in this kind of celebratory discourse: it was the modern, intellectualistic, tongue-in-cheek version of the cult. It had a certain striking and surprising quality. It became very popular with school festivities and contests and, of course, it was welcomed by textbooks. It thus falls under one criterion of texts likely to be parodied, (notwithstanding its own subtle ironic tonality): it enjoyed notoriety across many sections of the cultural system:

Parody demands a widely known target which is rich in typical, unmistakable features or idiosyncrasies. Well-known targets have the important advantage that the prospective readers of the parody will presumably realize the 
POPESCU

intertextual reference, which will enable them to appreciate the parody. (Beate Müller, Hamlet at the Dentist's. Parodies of Shakespeare, in Müller 1996: 136)

The first line of Sorescu's poem is a shocking statement, which denies Eminescu's historical existence: "Eminescu did not exist". However, the name detains a signifier. It needs a signified, which will predictably be a cultural signified, composed of such elements as: folklore, beautiful landscapes and the glorious national history. "Eminescu" is, by now, a symbolic name/ label in the Romanian collective imaginary. The symbolic meaning attributed to the poet's name is in fact a complex configuration of transindividual elements which are going to be carefully (and beautifully) detailed in Sorescu's metaphorical description. The legitimizing logic of myth, as described by Roland Barthes (1957), underlies the whole configuration, despite the presence of some decorative ironies:

Eminescu did not exist.

Only a beautiful country existed,

At a sea's margin

$[\ldots]$

But, above all, there were some simple people

Whose name were Mircea the Old, Stephen the Great

Or, more simply put: shepherds and ploughmen

Who enjoyed sitting at night by the fire and recite poems:

The Little Ewe and The Evening Star and The Third Letter.

But because they kept hearing the dogs barking at their sheepfold

They went fighting against the Tartarians

And the Avars and the Huns and the Polish

And the Turks." (Sorescu 1976: 54, my trans.) ${ }^{1}$

The Little Ewe is a Romanian ballad which, in the version slightly revised by the Romantic writer Vasile Alecsandri, has become a symbol of Romanian identity. The shepherd's strange lack of reaction to the little ewe's ominous prophecy that two of his fellows are planning to kill him has generated countless interpretations, some of them utterly extravagant. The two other poems, on

„Eminescu n-a existat. // A existat numai o țară frumoasă/ La o margine de mare // [...] / Şi, mai ales, au existat nişte oameni simpli / Pe care-i chema: Mircea cel Bătrân, Ştefan cel Mare, / Sau mai simplu: ciobani şi plugari, / Cărora le plăcea să spună, / Seara, în jurul focului poezii /Miorița şi Luceafărul şi Scrisoarea III/Dar fiindcă auzeau mereu /Lătrând la stâna lor câinii,/ Plecau să se bată cu tătarii/Şi cu avarii şi cu hunii şi cu leşii/ Şi cu turcii.” 
the other hand, The Evening Star and The Third Letter, belong to the national poet. A deliberate anachronism with some Borgesian overtones (the historical figures evoked here preceded Eminescu by several centuries) supports the poem's main "thesis", namely that the national poet is the quintessence of all the positive aspects of the autochthonous spiritual make-up. It is as if The Evening Star (his poetic masterpiece, on the theme of the Romanic "genius") and The Third Letter (a warm evocation of the medieval military and political leader Mircea the Old) existed before Eminescu, as collective archetypes. In fact, it is quite significant that they appear on the same level as folklore. The poet's individuality seems to have disappeared in the process, along with his status of a nineteenth-century Romantic poet. It is true that the most personal chapter of his body of work, erotic poetry, is also alluded to, but at the same time it is subjected to the same treatment of a quixotic literalization of literary themes and possible worlds: "There were also some linden-trees/ And two lovers/ Who knew how to snow up their flowers/ In a kiss"2 (Sorescu 1976: 55). Consequently, the entangled symbolic configuration that the poem displays is perfectly reducible to the trite cliché "Eminescu - the national poet". While per se this pious topos should not be that offensive, as practically every community strengthens its identity by identifying with iconic figures, the periphrasis has been so much abused during the last phase of the communist regime that it risked being equated with a typical nationalistic excess. In Sorescu's poem, the cliché works as a generative hypogram (cf. Riffaterre 1978: 21): though it might not be literally present, in the surface structure, it is the semantic nucleus, the invariant with respect to which the various tropes and images act as variants. Overdetermination, conversion and expansion are the rules governing the creation of the hypogram. Its textual expansion has an implicit argumentative function. The tinge of ironic hyperbole functions as emphasis and a supplementary persuasive strategy due to its effect of aesthetic novelty. On the other hand, the myth is reinforced and legitimized. Hutcheon's hypothesis about the "transideological politics" of irony (1994: 9), which can endorse both progressive and conservative ideals, is thus confirmed. The pious reception of the poem comfortably obliterated the irony (if there is indeed irony here) and kept the eulogy. Furthermore, the poet was in no way disturbed by the canonical status acquired by his poem.

Sorescu's experiment raises a challenge as regards the semantics of proper names (cf. Gouvard 1998): "And because all these had to bear a name /

2 "Au mai existat şi nişte tei,/ Şi cei doi îndrăgostiți/ Care ştiau să le troienească toată floarea/ Într-un sărut.” 
POPESCU

A single name/ They were called/ Eminescu"3 (Sorescu 1976: 56). In the last stanza the "bouquet" of cultural semes is brought back together so that Eminescu's name is recomposed as a motivated sign, a symbol, since the poetic argumentation has established a relation of necessity between the signifier and the signified (the one previously attributed by the poem itself, as we have seen). As a consequence of the metaphoric - mythological treatment, we must agree that indeed Eminescu as a unique historical person and a $19^{\text {th }}$-century poet in possession of an (also unique) style does no longer exist. He has become an artefact, a cultural emblem, practically, a brand. Mutatis mutandis, this kind of symbolic production was the communist equivalent of consumerist commodification.

The hypertext re-uses or "quotes" the framework of the hypotext, thus illustrating the overlapping between irony, which is primarily a trope or device and parody and satire which are genres (cf. Hutcheon 1981). By mimicking the structure of Sorescu's poem while inverting its meaning or message, Popescu's parody de-naturalizes and de-doxifies the stereotypes underlying the cultural myth reconfirmed and re-validated by his predecessor's apparently innovative rhetoric. The canonical emblem is substituted by another, which will predictably be attributed a cultural signified, consisting in rather negative elements:

Caragiale did not exist. There only was a beautiful and sad country where virtually everybody was condemned to pub-for-life. With beer-mugs chained at their wrists. So that taverns would rattle at every sip. There was a sort of worn out paradise in the trees of which would grow hen claws and necks and especially pork feet and heads. But the women of the land would in vain tempt their husbands to taste those things. For no matter how greedily they would have bitten, they still weren't able to fall out of that paradise. [...] / No. Caragiale did not exist. What did exist were some destroyed cemeteries, excavated by bulldozer. So that first-grade kids could come and write calligraphically, notch with a little knife on every skull of every skeleton: MADE IN ROMANIA. So that our dead be the very first, the champions of them all, volunteers there at resurrection, at The Final Judgment. [...] / And because all these had to bear a name, a single name and in order for that people to be able to roar with laughter at all these - they were simply called: Caragiale. (Popescu 1994: 62, my trans. $)^{4}$

\footnotetext{
3 "Şi pentru că toate acestea trebuiau să poarte un nume / Un singur nume / Li s-a spus/ Eminescu."

4 "Caragiale n-a existat. A existat numai o țară frumoasă şi tristă în care mai toți oamenii erau condamnați la crâş̧mă pe viață. Cu halbe de bere legate la-ncheietura mâinii în
} 
Ion Luca Caragiale (1852-1912) was the perfect candidate for representing Eminescu's symbolic counterpart. In a certain sense, Romanian culture (re) presents itself as a Janus Bifrons, having a solemn, almost hieratic, ideal face (Eminescu) and a sarcastic and hilarious face (Caragiale). Ion Luca Caragiale, Eminescu's contemporary, was a satiric writer, notorious mostly for his comic plays and his sketches. The two writers outline in their works two antonymic versions of the national "soul". The first image flatters national pride, while the second is uncomplacent, demystifying and even self-deprecating. Caragiale has created memorable (stock) characters, for example Mache, Lache or Mitică (in the sketches), Trahanache, Cațavencu, Dandanache, Mița, Veta, Zoe (in the comedies): shallow and unreliable individuals, prone to compromise and betrayal, the perfect antithesis of any heroic and altruistic ideal. Many critics hastened to equate these features to a realistic depiction of the national ethos.

Popescu's text displays a high level of heterogeneity and hybridization. Caragiale's stylemes are grafted on the lofty style of the ballad (traditionally interpreted as an identitary myth). The effect is grotesque, insofar as the "totemic" oracular animal, the little ewe (Miorița), faithful to her master, has been identified to Mița, an adulterous hysteric female character in one of Caragiale's comedies (D'ale carnavalului - Carnival Time). Her betrayal and her frivolous attitude are supposed to be typical for all Romanians. Not only does Popescu replace an iconic figure by another; he also replaces a cultural cliché by a series of stereotypes regarding ethnic character. Moreover, he seems to endorse them. The logic of replacement is crucial for understanding the deconstructive dimension of parody. The misleading sameness established by the title of the hypertext, a literal quotation of the title of the hypotext, will eventually reveal the radical difference of the polemic intertext.

lanțuri. De zăngăneau cârciumile la fiecare sorbitură. A existat un fel de rai ponosit în pomii căruia creşteau gheare şi gâturi de găină şi mai ales picioare şi capete de porci. Dar femeile acelui loc îşi îmbiau degeaba bărbații să guste din ele. Căci oricât au muşcat ei de pofticioşi n-au reuşit să cadă de tot din raiul acela. [...] / Nu. Caragiale n-a existat. Au existat nişte cimitire desfundate, săpate cu buldozerul. Ca să vină copilaşii de clasa întâi şi să caligrafieze, să scrijelească cu un cuțitaş pe toate țestele scheletelor: MADE IN ROMANIA. Ca să fie morții noştri cei dintâi, ăi mai prima din toți, volintiri acolo la-nviere, la Judecata din Urmă. [...] / Şi pentru că toate acestea trebuiau să poarte un nume, un singur nume, şi pentru ca oamenii aceia să poată hohoti în voie de toate acestea - li s-a spus simplu: Caragiale...” 
POPESCU

\section{Quotations with metalinguistic and metapoetic effects}

In the postmodern poetic frame, the material enclosed in quotation marks is both used and mentioned. It generates autonymic modalization. The mentioning dimension of quotation is part of what has been called "language turned on itself": quotation is "our primary metalinguistic tool" (Cappelen \& Lepore 2007: 1). Quotation marks and italics (or other iconic strategies for drawing attention to the words) reinforce the self-reflexive use of language.

"Quoted" sentences or fragments that do not seem to be ascribable to anyone in particular are used as building-blocks of the poetic meaning and commented upon in Radu Andriescu's series of poems Mirror Against the Wall: "'This is the first time I've written at five in the morning' / is a sentence with which I feel tempted to perpetrate a literary fraud [...]" (Andriescu 1992: 18, trans. by Adam Sorkin) ${ }^{5}$

During the nineties, the idea that the newly gained freedom of speech could be also liberating for the poetic discourse proved to be just another "doxic" preconception, like in the poem Curriculum vitae by Letiția Ilea:
so I write «god. church. black. angel.»
look how these words give me the illusion of freedom
they couldn't have been published a few years ago so what
I won't enter the history of literature just for that
meanwhile I am still there training the black cat
to go into my way every morning
so I may have someone to blame. (Ilea 1999: 8, my trans.) ${ }^{6}$

Free words are here denounced as empty words. This unusual string of "parole in libertà" illustrates the process that Bakhtin termed reification (1981: 336): when words are displayed, exhibited like this, outside a living context, they lose the basic capacity to refer and to mean something. With the censorship gone, after the revolution of 1989, these "dangerous" words are no longer forbidden, and therefore no longer subversive; they are given back to their rightful "owners", except that now they are devoid of meaning (or at least of that surplus of meaning that the political context was lending them). The locutor is free to

\footnotetext{
“《E prima dată când scriu la ora cinci dimineața» / e o frază cu care mă simt tentat să comit un fals literar."

6 "scriu deci «dumnezeu. biserică. negru. înger. » / uite cum îmi dau iluzia libertății aceste cuvinte/ n-ar fi apărut acum câțiva ani şi ce dacă/n-o să intru cu asta în istoria literaturii / şi eu tot acolo sunt dresând pisica neagră/ să-mi iasă în cale în fiecare dimineață/ să am şi eu pe cine da vina.”
} 
utter them, to enunciate them, but she is (yet) incapable to lend them a living/ lived, authentic context. Anyhow, they could never have the same illocutionary force within the new parameters of the literary institution. At the same time, inner freedom is not automatically gained and it might not be coincident with the change of political regimes or dominant ideologies - this is what the poem seems to suggest.

\section{Reported speech and polyphony}

Mikhail Bakhtin (1984) has extrapolated the concept polyphony from the musical field. Obviously, in the Russian author's studies, it refers mostly to the novelistic discourse, where different, often conflicting voices and points of view intersect and mingle. Dostoevsky's prose is the epitome of this complex feature of narrative. When reduced to the Romantic-lyric model of expressing subjectivity, poetry is indeed monologic/ monophonic. It displays much less dialogism and polyphony than the novel. Still, in hybrid, postmodern texts, multivocality finds its rightful place. In many Romanian contemporary poems there is a tendency to reproduce real or imaginary conversations or fragments of conversation. Interior monologue intertwined with simulated dialogue has become a rhetorical strategy with polyphonic effects. Direct, indirect speech, free indirect quotation, with or without quotative verbs - all situations are represented.

One consequence is the apparent enunciative "vanishing" of the poetic Subject or the Locutor. These so-called realistic "snapshots" may take the form of overheard conversations, diary-like registering of apparently trivial events or encounters that occur in the course of the day and more or less realistic descriptions of other people's banal or weird gestures and utterances. Conversely, the mimetic convention is replaced, in other poets' productions, by imaginary projections, fantastic or absurd scenarios with symbolic value.

If I were to formulate an interpretive hypothesis as to the significance of this widespread poetic practice, I would place it between the extremes of empathetic vs. ironic "ventriloquism". Also, it could be the postmodern response to what Simon Dentith has called "karaoke culture", with reference to contemporary popular culture. By that, the author understands the "voracious circulation of cultural material" and "an obsessive recycling or revoicing" (Dentith 2000: 184). In the case of literary quotations, the technique functions as the perfect antithesis and, at the same time the catharsis to the inescapable "anxiety of influence" (cf. Bloom 1973). Of all possible reasons for invoking other discourses in the space of one's writing I want to remind two: the ethical 
POPESCU

one and the heuristic one. Postmodern authors are comfortable with being hospitable "orchestrators" of various intertexts and, at the same time, they need other points of view in order to accurately articulate a certain topic, in order to be more persuasive and authentic.

Multi-layeredness and "enunciative heterogeneity" (Authier-Revuz 1984) are obvious consequences of this procedure of inviting other voices and other consciousnesses in what ought to be (according to the traditional model of the lyric genre), the emanation, the effusion of one single, unique voice, of one particular subjectivity and sensitivity. Polyphonic strategies will inevitably undermine any coherent model of poetic representation. The reader senses that 'the quotation radically interrupts the poem's voice; disrupting the discursiveness of a poem causes the poem's persona to diminish in centrality" (Diepeveen 1993:100).

Impersonating other people's voices and points of view relies on the speaker's metarepresentational and metacognitive abilities. The device can be misleading, in that it usually tells more about the quoter's inner world than about the original speaker. The talk poetry practiced by postmodernists plays upon this very ambiguity. The subject's status in postmodern poetry is quite complicated: configured on the background of the poststructuralist undermining of a unitary subject, postmodern literature has found multiple ways of re-focusing on identitary issues. Stylization and hybridization are modes associated with the various types of inserting the others' discourses into one's own. These devices are quite "natural" to postmodern poetry. They reflect Bakhtin's prophecy about the novelization of various genres (cf. Bakhtin 1981: 39).

Of course, with many of the poems the alien inputs are blatantly fictive. The master of pseudo-polyphony is in this respect Cristian Popescu, who attributes incredible monologues to the members of his family, turning them into grotesque - mythic characters; their discourses, however, are not stylistically distinguishable from the idiolect associated with the main locutor, the poet's persona ("Popescu") and are in fact embedded in the "master" discourse - an irrepressible stream of consciousness of a person tormented by persistent anxiety:

With my Cristi, you've got to understand him. He may be saying a lot of things about us, but you mustn't take him seriously. He loves and respects us. [...] That's him. He's not made for this world. [...]” Mother's very considerate. When I cut the bread, she bandages it, and when I break it, mother immediately 
Quotation as a Poetic Device in a Romanian Postmodern Corpus

puts it in a plaster cast. (Cr. Popescu, Advice from My Mother, in Bodiu et al. 1999: 209, tr. by Adam J. Sorkin \& B. Ştefănescu. $)^{7}$

We will not infer from here, however, that this kind of quotation use is a proof of a parasitic use of language characteristic to poetry. Even in everyday exchanges, reported speech need not have a content previously uttered. People frequently "quote" inner thoughts, or attribute sentences to other persons in order to tell a coherent and vivid story. Besides, there is such a thing as "hypothetical reported discourse" (Myers 2000) and "quoting the unspoken" (Sams 2007). Researchers agree that the opposition between the real and the invented quoted discourse is immaterial. Even in poetry, „all quoting exploits an alien texture, whether such texture be real or imagined" (Diepeveen 1993: 15).

\section{Conclusions}

Inside the embedding palimpsest the borrowed fragment can be either disruptive or enriching. With respect to the dialogic/ interdiscursive dimension, the quoted discourse is treated as:

1) an object (reified, displayed, exhibited) - intertextuality in the poststructuralist sense;

2) a voice, a manifested Other - polyphony, dialogism, intersubjectivity.

In the case of fake citations, what is actually cited is the gesture, the action of citing, with the pragmatic prerequisites attached to it; or, we could, say, the shape of standard quotation is used for various communicative purposes. The invented quote produces its own pre-text, making the quoted simultaneous with the quoting discourse. This unreliable use of the quoting activity exploits some features inherent in "normal" quotation, which already includes an important part of simulation (cf. Recanati 2001).

By exploiting the intertextual presupposition, Romanian postmodern poets extrapolate and re-frame the "serious" way of appropriating another discourse, without giving away any of the liberties and advantages inherent to the literary game: indirection, obliqueness, vagueness, concealing, misquoting, misattribution, "ungrammaticalities" etc. Quotation detains, in the context of poetic postmodernism, on the one hand, an argumentative/ persuasive function, and, on the other hand, an aesthetic function.

\footnotetext{
"Pe Cristi trebuie să-1 înțelegeți. Spune o mulțime de lucruri despre noi, dar nu trebuie să-1 luați în serios. Ne iubeşte şi ne respectă. [...] Aşa e el. Nu e făcut pentru lumea asta. [...] Mama e foarte grijulie. Când tai pâinea, o bandajează, şi când o rup, mama o pune imediat în ghips." (Popescu 1988: 20)
} 
POPESCU

\section{Carmen Popescu}

cpopescu71@gmail.com

Bulevardul 1 Mai, no. 75, Bl. 25, sc. 2, ap. 2

Craiova

Dolj 200334

ROMÂNIA

\section{References}

Andriescu, R. 1992. Oglinda la zid. Iaşi: Canova.

Andriescu, R. 1999. Mirror Against the Wall [A. Sorkin, tr.]. - Exquisite Corpse. A Journal of Letters and Life, November-December, Issue 2, http://www.corpse.org/ archives/issue_2/burning_bush/sorkin.htm (16.11.2014).

Authier-Revuz, J. 1984. Hétérogénéité(s) énonciative(s). - Langages, 19, 98-111.

Bakhtin, M. 1981. The Dialogic Imagination: Four Essays. [C. Emerson, M. Holquist, tr., M. Holquist, ed.] Austin: University of Texas Press.

Bakhtin, M. 1984. Problems of Dostoyesky's Poetics. [C. Emerson, tr.] Minneapolis: University of Minnesota Press.

Barthes, R. 1957. Mythologies. Paris: Seuil.

Barthes, R. 1977. The Death of the Author. - Image, Music, Text. [S. Heath, tr.] New York: Noonday, 142-148.

Bloom, H. 1973. The Anxiety of Influence. A Theory of Poetry. New York: Oxford University Press.

Bodiu, A., Bucur, R., Moarcăş, G. 1999. Romanian Poets of the 80's and'90's. A Concise Anthology. Piteşti: Paralela 45.

Cappelen, H., Lepore, E. 2007. Language Turned on Itself. The Semantics and Pragmatics of Metalinguistic Discourse. Oxford: Oxford University Press.

Clark, H. H., Gerrig, R. J. 1990. Quotations as demonstrations. - Language, 66 (4), 764-805.

Compagnon, A. 1979. La seconde main ou le travail de la citation. Paris: Seuil.

Culler, J. 1981. The Pursuit of Signs. Semiotics, Literature, Deconstruction. Ithaca, New York: Cornell University Press.

Davidson, D. 1984. Quotation in Inquiries into Truth and Interpretation. Oxford: Oxford University Press.

Dentith, S. 2000. Parody. London \& New York: Routledge.

Diepeveen, L. 1993. Changing Voices: The Modern Quoting Poem. Ann Arbor: University of Michigan Press.

Garber, M. 2003. Quotation Marks. New York: Routledge.

Genette, G. 1997. Paratexts. Thresholds of Interpretation. [J. E. Lewin, tr.] Cambridge: Cambridge University Press.

Genette, G. 1998. Palimpsests: Literature in the Second Degree. [Ch. Newman, tr.] Lincoln: University of Nebraska Press. 
Quotation as a Poetic Device in a Romanian Postmodern Corpus

Gouvard, J.-M. 1998. La pragmatique. Outils pour l'analyse littéraire. Paris : Armand Colin.

Gregory, E. 1996. Quotation and Modern American Poetry. "Imaginary Gardens with Real Toads". Houston, Texas: Rice University Press.

Hassan, I. 1987. The Postmodern Turn. Essays in Postmodern Theory and Culture. Columbus: Ohio University Press.

Hutcheon, L. 1981. Ironie, parodie, satire. Une approche pragmatique de l'ironie. Poétique, 46, 140-155.

Hutcheon, L. 1988. A Poetics of Postmodernism. History, Theory, Fiction. New York: Routledge.

Hutcheon, L. 1994. Irony's Edge. The Theory and Politics of Irony. New York: Routledge. Ilea, L. 1999. Chiar viața [Life Itself]. Piteşti: Paralela 45.

Jameson, F. 1991. Postmodernism, or The Cultural Logic of Late Capitalism. Durham: Duke University Press.

Kristeva, J. 1980. Desire in Language: A Semiotic Approach to Literature and Art. [L. Roudiez, ed., Th. Gora, A. Jardine, L. Roudiez, tr.] New York: Columbia University Press.

Myers, G. 2000. Unspoken speech: hypothetical reported discourse and the rhetoric of everyday talk. - Text, 19, 571-590.

Müller, B., ed. 1996. Parody. Dimensions and Perspectives. Amsterdam: Rodopi.

Parpală-Afana, E. 1994. Poezia semiotică. Promoția 80. Craiova: Sitech.

Plett, H., ed. 1991. Intertextuality. New York: de Gruyter.

Popescu, C. 2010. Pragmatica peritextului în poezia postmodernă. - E. Parpală, C.

Popescu, eds., Comunicare, identitate, cultură. Craiova: Universitaria, 119-131.

Popescu, Cr. 1988. Cuvânt înainte [Foreword]. Bucureşti: Cartea Românească.

Popescu, Cr. 1994. Arta Popescu [Art Popescu]. Bucureşti: Societatea „Adevărul S.A.”

Recanati, F. 2001. Open Quotation. - Mind, 110, 637-687.

Riffaterre, M. 1978. Semiotics of Poetry. Bloomington: Indiana University Press.

Riffaterre, M. 1979a. La syllepse intertextuelle. - Poétique, 40, 496-501.

Riffaterre, M. 1979b. Sémiotique intertextuelle: L'Interprétant. - Revue d'Esthétique, $1-2,128-150$.

Riffaterre, M. 1990. Compulsory reader response: the intertextual drive. - M. Worton, J. Still, eds., Intertextuality: Theories and Practices. Manchester \& New York: Manchester University Press, 56-78.

Saka, P. 2005. Quotational Constructions. - Belgian Journal of Linguistics, 17, 187-212. Sams, J. 2007. Quoting the Unspoken: An analysis of quotations in spoken discourse. Colorado Research in Linguistics, June, Vol. 20, Boulder: University of Colorado, http://www.colorado.edu/ling/CRIL/Volume20_Issue1/paper_SAMS.pdf (16.11.2014).

Sorescu, M. 1976. Poeme [Poems]. Bucureşti: Albatros.

Sorescu, M. 1991. Hands Behind My Back, Introduction by Seamus Heaney. [G. Dragnea, S. Friebert, A. Varga, tr.] New Hampshire: University Press of New England. 